\title{
PENGETAHUAN PEDAGOGI KANDUNGAN GURU BAHASA IBAN YANG BAHARU DENGAN YANG BERPENGALAMAN DI SEKOLAH-SEKOLAH MENENGAH DI SARAWAK
}

PEDAGOGICAL CONTENT KNOWLEDGE OF NOVICE AND EXPERIENCED IBAN LANGUAGE TEACHERS IN SARAWAK SECONDARY SCHOOLS

\author{
${ }^{1}$ Magdeline Anak Nor \& ${ }^{2}$ Zamri Mahamod \\ ${ }^{1,2}$ Faculty of Education \\ Universiti Kebangsaan Malaysia \\ ${ }^{2}$ Corresponding author: d-zam@ukm.my
}

\begin{abstract}
ABSTRAK
Tujuan - Keberkesanan dan kepakaran seseorang guru dapat dinilai melalui teknik pengajarannya. Oleh itu, fokus akan diberikan kepada proses pengajaran guru bahasa Iban untuk memastikan keberkesanan pengajaran guru-guru bahasa Iban di Sarawak. Kajian ini dijalankan berdasarkan teori yang diperkenalkan oleh Shulman, iaitu Pedagogical Content Knowledge (PCK) atau juga dikenali sebagai Pengetahuan Pedagogi Kandungan (PPK).
\end{abstract}

Metodologi - Kajian kualitatif ini dijalankan untuk meneroka dan meneliti secara mendalam pengetahuan pedagogi kandungan (PPK) yang dimiliki oleh guru bahasa Iban baharu dan berpengalaman di sekolah menengah di Sarawak. Tiga orang guru bahasa Iban dari Pejabat Pendidikan Daerah (PPD) Subis dan seorang guru bahasa Iban dari PPD Miri dipilih sebagai peserta kajian temu bual dan pemerhatian. Transkrip temu bual dianalisis secara teliti dengan bantuan perisian QSR Nvivo9.

Dapatan - Kajian mendapati bahawa PPK guru-guru bahasa Iban dipengaruhi oleh disiplin ilmu masing-masing kerana kesemua guru 
bahasa Iban berlatar belakangkan pengkhususan yang berbezabeza. Dapatan kajian juga menunjukkan tidak ada perbezaan PPK yang ketara antara guru berpengalaman dan guru yang baharu. Sebaliknya faktor keperibadian guru yang membezakan penguasaan PPK guru, sama ada guru tersebut baharu atau berpengalaman hanya menjadi faktor sampingan sahaja. Strategi pedagogi kandungan guru-guru bahasa Iban juga didapati dipengaruhi oleh latar belakang pengkhususan mereka. Pemerhatian pengkaji mendapati PPK yang baik terhasil apabila seorang guru itu benar-benar menghayati dan menghargai mata pelajaran bahasa Iban.

Kepentingan - Kajian ini penting kepada pihak pengurusan sekolah agar memastikan guru-guru bahasa Iban yang berkelayakan sahaja yang dibenarkan mengajar mata pelajaran bahasa Iban.

Kata kunci: Pengetahuan pedagogi kandungan, guru bahasa Iban, sekolah menengah.

\section{ABSTRACT}

Purpose - The efficiency and expertise of a teacher is reflected in his or her teaching technique. In this paper, focus is given to the teaching process of Iban language subject teachers in order to determine the effectiveness of their teaching. The study was based on Shulman's pedagogical content knowledge (PCK) theory. It explored and deeply examined PCK among Iban language subject teachers in secondary schools in Sarawak.

Methodology - This qualitative study focused on both novice and experienced Iban language subject teachers. Three teachers from the Subis Education Department Office and one teacher from the Miri Education Department Office were chosen to be interviewed and observed. The transcripts of the interview were analysed utilising QSR Nvivo9 software.

Findings - PCK among the teachers was found to be influenced by their discipline of knowledge, as most of them come from different specialisations. There was no difference between experienced and new teachers. Rather, it is personal factors that made a difference in the teachers' PCK, and whether the teachers are new or experienced is 
just a minor factor. The PCK of Iban language teachers is also found to be influenced by their respective specialisations. Observations revealed that the best PCK teacher is produced when a teacher truly absorbs and appreciates the Iban language subject itself.

Significance - This study is important to the school management to ensure that the Iban language teachers are qualified to teach the Iban Language subject.

Keywords: Pedagogical content knowledge, Iban language teacher, secondary school.

\section{PENGENALAN}

Malaysia dikenali sebagai sebuah negara yang unik kerana rakyatnya terdiri daripada pelbagai kaum. Buletin Perangkaan Malaysia (2006) memaparkan tiga kaum yang utama di Malaysia ialah Melayu (13.48 juta orang atau 54\%), Cina (6.22 juta orang atau $25 \%$ ) dan India (1.86 juta orang atau $7.5 \%$ ). Selain daripada tiga kaum yang utama tersebut, terdapat juga 2.93 juta orang (11.8\%) kaum Bumiputera bukan Melayu. Kaum Bumiputera bukan Melayu tersebut terdapat di negeri Sabah dan Sarawak. Populasi Bumiputera bukan Melayu yang terdapat di Sabah dan Sarawak terdiri daripada berpuluh-puluh kumpulan etnik yang bertutur menggunakan bahasa yang berbeza, tetapi mengamalkan budaya umum yang hampir sama (Sarawak Government Official Portal, 2010). Kepelbagaian kaum di Malaysia telah melahirkan bahasa dan juga dialek yang berbeza dalam kalangan rakyatnya. Walau bagaimanapun, bahasa Melayu telah dijadikan bahasa Kebangsaan dan bahasa pengantar dalam kalangan rakyatnya yang berbilang kaum.

Penggunaan bahasa Melayu tidak meminggirkan penggunaan bahasa Inggeris. Bahasa Inggeris turut diajar sebagai bahasa kedua di semua sekolah yang terdapat di Malaysia. Bahasa Cina dan Tamil juga diajar dengan meluas sehingga tertubuhnya sekolahsekolah aliran bahasa Cina dan juga bahasa Tamil (Bernama, 2007). Selain bahasa Melayu, Cina dan India, bahasa etnik juga turut ditawarkan di Malaysia. Setakat ini, terdapat tiga bahasa etnik yang sudah ditawarkan di sekolah-sekolah kerajaan, iaitu bahasa Iban, Kadazandusun dan Semai. 
Bahasa Iban ditawarkan di sekolah-sekolah yang terdapat di Sarawak, bahasa Kadazandusun ditawarkan di negeri Sabah dan bahasa Semai pula ditawarkan di negeri Perak dan Pahang (Unit Bahasa Etnik, Pusat Perkembangan Kurikulum 2007b). Bahasa Iban ialah bahasa yang dituturkan oleh kaum Iban di Sarawak. Kaum Iban merupakan kumpulan etnik terbesar negeri Sarawak (Sarawak Government Official Portal, 2010). Faktor tersebut mungkin menjadi punca jumlah pelajar yang mempelajari bahasa Iban jauh lebih besar berbanding dengan bahasa Kadazandusun dan bahasa Semai (Unit Bahasa Etnik, Pusat Perkembangan Kurikulum 2010).

Pembelajaran yang berkesan berkait rapat dengan pengajaran guru. Dapatan kajian menunjukkan pengetahuan dan kepercayaan guru terhadap pengajarannya akan mempengaruhi corak pembelajaran pelajar-pelajarnya (Solis, 2009). Dalam konteks pengajaran dan pembelajaran bahasa Iban, tidak dapat dinafikan pengetahuan dan pengajaran guru akan mempengaruhi corak pembelajaran pelajarpelajar Iban. Shulman (1987) berpendapat Pengetahuan Pedagogi Kandungan (PPK) menjadi teras pengetahuan guru yang terpenting. Pengetahuan kandungan merujuk kepada bidang pengetahuan guru tentang isi kandungan mata pelajaran bahasa Iban dan pengetahuan pedagogi pula adalah berkaitan dengan pengetahuan mengenai strategi pengajaran yang khusus.

Shulman (1987) pernah mencadangkan untuk mengetahui cara keberkesanan dan kepakaran guru adalah dengan memberi tumpuan kepada proses pengajaran guru tersebut. Oleh itu, proses pengajaran guru bahasa Iban juga akan diberi tumpuan untuk memastikan keberkesanan pengajaran guru-guru bahasa Iban di Sarawak. Sehubungan itu, kajian ini dilaksanakan untuk meneroka PPK guruguru bahasa Iban di Sarawak. Penggunaan PPK guru semasa proses pengajaran akan diteliti secara mendalam. Hal ini kerana, PPK bukan sahaja melibatkan kefahaman guru terhadap pengetahuan isi kandungan bahasa Iban yang disampaikan kepada pelajar, tetapi juga keupayaan mereka mempelbagaikan kaedah pengajaran agar mudah difahami oleh pelajar. Walau bagaimanapun, tidak dapat dinafikan keupayaan guru bahasa Iban mengajar mata pelajaran tersebut dengan berkesan amat bergantung kepada pengalaman, pengetahuan isi kandungan dan kemahiran pedagogi mata pelajaran tersebut (Shulman, 1987). 


\section{PENGETAHUAN PEDAGOGI KANDUNGAN}

Istilah Pedagogical Content Knowledge (PCK) atau juga dikenali sebagai Pengetahuan Pedagogi Kandungan (PPK) telah diperkenalkan lebih 20 tahun yang lalu (Ball, Thomas \& Phelps, 2007). Penyelidik dalam bidang akademik masih menggunakan PPK untuk merujuk pengetahuan tentang subjek dan pengetahuan tentang pengajaran. PPK telah dikembangkan merentasi pelbagai bidang ilmu dan telah dipetik lebih daripada 1,200 orang penyelidik (Ball, Thomas \& Phelps, 2007). Burns dan Lash (1988) telah membezakan pengetahuan pedagogi dengan PPK. Menurut mereka, pengetahuan pedagogi merujuk kepada cara menstrukturkan dan mengendalikan pembelajaran. Manakala, PPK pula merujuk kepada pelbagai cara untuk mengajar topik yang spesifik dalam sesuatu mata pelajaran.

PPK sebenarnya mula diperkenalkan pada akhir 1980-an oleh Shulman yang telah mengendalikan kajian kes yang dikenali sebagai Knowledge Growth in Teaching terhadap guru sekolah menengah. Peserta kajian tersebut terdiri daripada lulusan dalam bidang Matematik, Sains, bahasa Inggeris, Kesusasteraan dan juga Sejarah (Ball et al., 2007). Shulman (1986) telah mengkaji beberapa kemungkinan sebab pengetahuan guru telah merosot pada masa lalu. Dapatan kajian Shulman mendapati 90 hingga 95 peratus guru-guru perlu menguasai, sama ada pengetahuan mata pelajaran atau asas pengetahuan am. Kajian ini telah dikembangkan lagi oleh rakanrakannya seperti Grossman dan Wilson et al. (Abdul Shatar, 2007).

Persoalan utama kajian Shulman (1986) adalah bagaimana mengubah seseorang yang pintar dengan pengetahuan kandungan menjadi guru baharu. Kajian ini mencetuskan idea kepada Shulman untuk membina satu kerangka teori yang boleh digunakan untuk menilai guru baharu. Beliau telah melihat unsur pengetahuan kandungan mata pelajaran, pengetahuan pedagogi kandungan dan pengetahuan kurikulum untuk menilai persediaan guru baharu. Selain itu, beliau turut memberi fokus kepada pengetahuan tentang permasalahan, pengetahuan kes dan pengetahuan strategi. Shulman (1986) telah mentakrifkan pengetahuan tentang kandungan adalah tentang fakta, sama ada fakta berkaitan dengan isi kandungan atau pedagogi. Manakala, pengetahuan kes pula merujuk kepada bagaimana guru mengelola kes-kes khas daripada pelbagai ragam pelajar atau emosi 
bilik darjah. Pengetahuan strategi pula merujuk kepada kebolehan untuk menyelesaikan konflik dengan mengetahui fakta dan kes. Pengetahuan ini dianggap pengetahuan peringkat tertinggi dalam paradigmanya.

PPK adalah konstruk yang digunakan Shulman untuk menjelaskan bidang pengetahuan guru mengenai isi kandungan (mata pelajaran) dan pedagogi (strategi pengajaran). PPK merupakan pemahaman guru mengenai cara membantu pelajar memahami sesuatu mata pelajaran secara khusus. Hal ini termasuklah pengetahuan tentang bagaimana tajuk-tajuk tertentu dalam sesuatu mata pelajaran, masalah dan isu-isu boleh disusun, dipersembahkan dan disesuaikan dengan pelbagai minat dan kebolehan pelajar dalam pengajaran dan pembelajaran. PPK akan membantu guru-guru dalam membuat analogi, metafora, memberi contoh, mengadakan pelbagai aktiviti dan tunjuk cara bagi membantu kejayaan pelajar (Shulman, 1986).

Carter (1990) berpendapat PPK adalah apa yang guru tahu tentang pengetahuan isi kandungan subjek dan bagaimana mereka menterjemahkan pengetahuan tersebut dalam aktiviti bilik darjah, konseptualisasi dan mengajar topik-topik khusus dalam sesuatu mata pelajaran. Menurut Gudmundsdottir (1991), PPK ialah pengetahuan isi kandungan guru yang telah dipindahkan menjadi sesuatu yang berbeza daripada sebelumnya ke bentuk aplikasi yang praktikal dalam pengajaran. Shulman (1987), Carter (1990), Magnusson, Borko dan Krajcik (1998) serta Gudmundsdottir (1991) sepakat mengatakan PPK berkait dengan proses transformasi daripada pengetahuan isi kandungan dan pengetahuan pedagogi untuk memudahkan sesi pengajaran dan pembelajaran. Malah, sorotan kajian mendapati seorang guru yang mempunyai PPK akan dapat meningkatkan keberkesanan pengajarannya (Shulman, 1987; Borko \& Putnam, 1996; Ball et al., 2007; Kauchak \& Eggen, 2007; Abdul Shatar, 2007).

Veal dan Makinster (1999) pula menghuraikan PPK dalam bentuk taksonomi am tentang PPK yang terdiri daripada PPK am, PPK domain khusus dan PPK topik khusus. Mereka telah mengelaskan pelbagai jenis PPK secara hierarki dan pengelasan ini dikenali sebagai taksonomi PPK am. Mereka menyatakan bahawa asas kepada taksonomi ini ialah pengetahuan pedagogi yang patut dikuasai oleh semua guru. Pengetahuan pedagogi terdiri daripada 
cara merancang, kaedah pengajaran, penilaian, kerja kumpulan, cara menyoal dan cara memberi maklum balas. Tengku Zawawi (2005) berpendapat taksonomi PPK yang dikemukakan oleh Veal (1999) selaras dengan langkah-langkah yang telah digunakan oleh Bloom. Taksonomi Bloom disusun mengikut fenomena tingkah laku, taksonomi bagi PPK pula telah dibentuk mengikut susunan aras pengkhususan.

Seorang guru pakar dalam PPK am mempunyai kefahaman yang baik tentang konsep pedagogi. PPK am lebih terperinci daripada pedagogi kerana menjurus kepada subjek seperti Matematik, Sains, Sejarah, Seni atau bahasa Inggeris (Veal \& MaKinster, 1999). Sebenarnya PPK am ini sama dengan dengan subject-specific PCK strategies yang diperkenalkan oleh Magnusson et al (1998). Orientasi PPK am boleh diimplementasikan kepada pelbagai subjek atau mata pelajaran lain, tetapi proses, tujuan dan isi kandungan tentunya berbeza (Veal \& Makinster, 1999).

PPK bidang khusus pula lebih jelas berbanding dengan PPK am kerana memberi tumpuan kepada satu daripada beberapa bidang yang berbeza (Veal \& Makinster, 1999). Bidang khusus mata pelajaran bahasa Iban ialah jalai jaku (tatabahasa), tanya saut (kefahaman), karang (karangan) dan litericha (sastera). Setiap bidang ini mempunyai pemahaman terhadap kurikulum dan bahan bantu mengajar yang berbeza. Walau bagaimanapun, bentuk dan instrumen penilaian setiap bidang adalah sama. Setiap bidang pula mempunyai topik-topik yang tertentu.

PPK topik khusus ialah tahap khusus dan terpenting dalam taksonomi ini (Veal \& Makinster 1999). Topik khusus sebenarnya pecahan topik daripada PPK bidang khusus. Misalnya, bidang litericha (sastera) bahasa Iban terbahagi kepada beberapa topik khusus seperti pantun, ensera, sabak, ganu, pelandai, jawang, ramban, sugi, renong, tanya indu, timang, pengap, pelian, sampi, naku pala dan banyak lagi (Chemaline, 2006). Guru yang mempunyai pengetahuan mendalam dalam PPK tahap ini, kebiasaannya telah menguasai pengetahuan dan kemahiran dalam dua tahap PPK sebelum ini.

Pada tahun yang sama dengan Veal dan Makinster (1999) serta Gess-Newsome (1999) telah memperkenalkan Examining Pedagogical Content Knowledge. Beliau berpendapat terdapat dua 
cara untuk melihat domain pengetahuan guru. Oleh itu, beliau telah mengetengahkan dua model PPK. Model tersebut ialah Integrative Model dan Tranformative Model. Integrative Model menunjukkan PPK sebagai bahagian-bahagian di antara pengetahuan kandungan, pengetahuan pedagogi dan pengetahuan kontekstual. Setiap bahagian pengetahuan guru tersebut boleh diuji secara bersendirian. Dalam proses pengajaran, setiap pengetahuan tersebut boleh digambarkan satu persatu. Integrative model digunakan untuk menerangkan pengetahuan guru baharu.

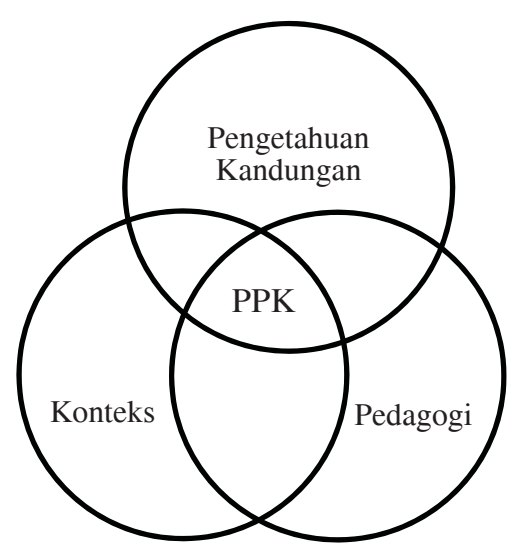

Rajah 1. Model Integratif Pengetahuan Pedagogi Kandungan (Gess-Newsome, 1999)

Model Transformatif pula menunjukkan pengetahuan kandungan, pengetahuan pedagogi dan pengetahuan kontekstual diterjemahkan ke dalam PPK yang kemudian menjadi dasar pengajaran guru terbabit. Model Transformatif selalunya digunakan untuk menerangkan pengetahuan guru berpengalaman. Model Transformatif Dapatan Ingber (2009) dalam Rajah 2 menunjukkan hubungan yang rumit antara konteks guru, pengetahuan kontekstual guru dan PPK guru akan mempengaruhi perancangan guru.

Kauchak dan Eggen (2007) telah meletakkan PPK sebagai pengetahuan kedua penting bagi seseorang yang ingin menjadi guru pakar. Hal ini kerana, mereka merasakan PPK merupakan cara yang efektif memindahkan maklumat yang akan difahami oleh pelajar. Sebaliknya, guru yang lemah PPK akan mengamalkan pengajaran 
yang bersifat tradisional, iaitu guru berkuliah, pelajar pula menghafal (Lilia \& Norlena, 2000). Cara pengajaran tradisional di Hong Kong pula, pengajaran berpusatkan guru (May, Annie \& Sylvia, 2010).

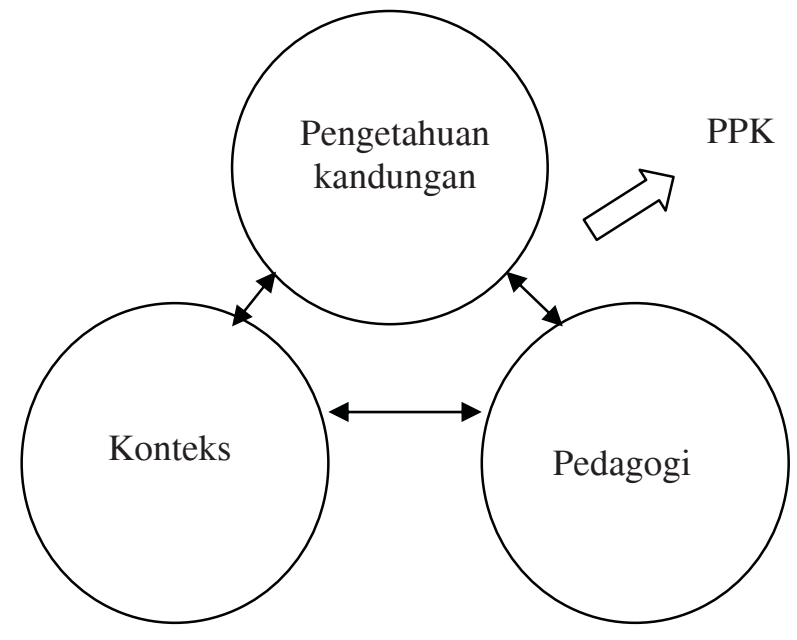

Rajah 2. Model Transformatif Pengetahuan Pedagogi Kandungan (Gess-Newsome, 1999)

Selain daripada pengetahuan isi kandungan dan pengetahuan pedagogi, PPK juga bergantung kepada pengetahuan guru terhadap ciri atau latar belakang pelajar yang diajarnya. Dua elemen penting yang terkandung dalam PPK ialah pengetahuan cara bagaimana isi pelajaran dapat disampaikan kepada pelajar dengan berkesan dan memahami masalah pembelajaran pelajar khususnya yang berkaitan dengan isi kandungan pembelajaran tersebut (Norasliza \& Zaleha, 2008).

PPK ialah masalah "learning to teach", iaitu bagaimana guru menterjemahkan pengetahuan daripada satu bentuk kepada bentuk yang lain, persoalan kepada aturan daripada menghuraikan makna pengalaman yang kompleks (Carter, 1990). PPK juga termasuk pengetahuan terhadap teknik-teknik penilaian penguasaan kemahiran dan kefahaman konsep pelajar serta strategi pengajaran agar isi pembelajaran dapat dibina dan difahami oleh pelajar secara bermakna (Wiseman, Cooner \& Knight et al. 1999). 
Walau bagaimanapun, Rosnidar, Lilia dan Kamisah (2010) mempunyai sedikit perbezaan pendapat dengan pengkaji sebelumnya. Mereka berpendapat bahasa PPK bukan hanya empat komponen, iaitu pengetahuan isi kandungan, pengetahuan pedagogi, pengetahuan tentang konteks dan, pengetahuan tentang pelajar. Sebaliknya mereka telah menambah satu lagi komponen, iaitu sikap dan emosi guru. Sikap dan emosi guru dikatakan memberi kesan positif dan juga negatif kepada pelajar. Mereka mendapati sikap guru yang bersungguh-sungguh mengajar membuatkan pelajar bersemangat dan berakhir dengan kefahaman pelajar. Sebaliknya, jika emosi guru tidak stabil dan asyik memarahi pelajar, maka pelajar akan bosan serta terganggu dan seterusnya pelajar tidak mendapat kefahaman dalam pembelajaran mereka.

\section{PERSOALAN KAJIAN}

Kekurangan kajian PPK terhadap mata pelajaran bahasa di Malaysia merupakan salah satu faktor kajian ini perlu dijalankan. Memandangkan belum ada kajian tentang PPK bahasa Iban sekolah menengah menyebabkan mata pelajaran ini masih lagi dianggap sebagai mata pelajaran yang terpinggir atau kurang penting. Hal ini kerana tanpa sesuatu kajian akan menyebabkan idea terhad untuk memperbaiki pengajaran dan pembelajaran, terutamanya untuk memahami hubungan antara pengetahuan, pengajaran dan pembelajaran pelajar (Ball et al., 2007). Hasrat pengkaji ini selaras dengan pendapat Nurul Hudaa, Nik Mohd Rahimi \& Kamarul Zaman (2010) yang mengatakan kajian seperti ini amat perlu dijalankan supaya setiap kelemahan atau kekuatan dapat dikenal pasti dan seterusnya diperbaiki atau dilakukan penambahbaikan.

Bahasa Iban pernah ditawarkan di peringkat pengajian tinggi pada tahun 1970-an, tetapi kajian mata pelajaran Bahasa Iban amat kurang dilaksanakan di Malaysia. Kajian yang ada lebih menjurus kepada tatabahasa bahasa Iban (Asmah, 1981), susur galur bahasa Iban (Asmah, 1985, 1993), fonologi bahasa Iban (Ismail 1991; Rahim, 1997 \& 2006; Shahidi, 2000), morfologi bahasa Iban (Rahim, 1997 \& 2006), dialek bahasa Iban (Chong Shin, 2006), bahasa Iban (Noriah 1994; Collins 2004) dan, puisi bahasa Iban (Chemaline, 2006). Kajian mereka tidak menjurus kepada bahasa Iban sebagai 
satu mata pelajaran yang ditawarkan di sekolah. Oleh itu, impak dan keberkesanan pengajaran guru-guru bahasa Iban tidak diketahui umum, termasuklah oleh guru-guru tersebut sendiri.

Hal tersebut membawa kepada salah faham antara guru bahasa Iban dan pelajarnya. Perkara tersebut berlaku dalam dapatan kajian Magdeline (2008). Dapatan kajian Magdeline menunjukkan guruguru pada pandangan pelajar telah menggunakan kelima-lima gaya pengajaran Model Grasha (1996). Pandangan pelajar tersebut berbeza dengan pandangan guru-guru yang menyatakan mereka tidak pernah langsung menggunakan gaya pengajaran pakar dan juga gaya pengajaran delegator. Malah dari segi sikap pelajar Iban terhadap mata pelajaran Bahasa Iban, hanya terdapat 37.5 peratus pelajar sahaja yang bersikap positif terhadap bahasa Iban.

Kekurangan kajian tentang mata pelajaran Bahasa Iban juga menyebabkan masalah-masalah yang timbul tidak diketahui oleh pihak-pihak yang berkepentingan seperti Pusat Perkembangan Kurikulum selaku perancang dan penggubal dasar pengajaran bahasa Iban. Semasa kajian ini dibuat, hanya Lambat (2007) dan Magdeline (2008) yang telah membuat kajian tentang mata pelajaran Bahasa Iban. Dapatan kajian Magdeline (2008) tentang sikap pelajar terhadap mata pelajaran Bahasa Iban amat baik di mana hanya 10 peratus sahaja pelajar mempunyai sikap negatif terhadap mata pelajaran Bahasa Iban, manakala 90 peratus menyukainya jika diajar.

Guru-guru bahasa Iban yang sedia ada terdiri daripada guru-guru mata pelajaran lain seperti guru Bahasa Melayu, Inggeris, Sains, Pendidikan Seni, Kesusasteraan Melayu, Geografi, Matematik dan lain-lain lagi. Guru-guru tersebut merupakan guru-guru etnik atau kaum Iban yang diarahkan oleh pihak sekolah untuk mengajar mata pelajaran Bahasa Iban. Sebenarnya mata pelajaran Bahasa Iban mengalami nasib yang sama seperti mata pelajaran Pendidikan Moral. Guru-guru Pendidikan Moral juga terdiri daripada mereka yang pelbagai latar belakang, pengkhususan dan pengalaman. Kebanyakan guru yang mengajar Pendidikan Moral ialah guru pengkhususan Sains Sosial, Sains Tulen dan Teknologi Maklumat. Malah, sebahagian guru tersebut hanya mempunyai pengalaman belajar mata pelajaran Bahasa Iban semasa belajar di sekolah menengah dahulu. Terdapat juga guru-guru baharu yang 
tidak terlatih dalam mata pelajaran Pendidikan Moral diarahkan mengajar untuk memenuhi keperluan sekolah bagi mencukupkan bilangan waktu mengajar atau mengisi tempat guru lain (Chong Yee Pei, 2000).

Selain daripada ilmu pengetahuan, proses penyampaian ilmu pengetahuan oleh guru kepada pelajar-pelajarnya juga amat penting. Guru yang berilmu pengetahuan tinggi, tetapi gagal untuk menyalurkan ilmunya kepada pelajar-pelajar sering disebut sebagai 'guru syok sendiri'. Guru perlu memastikan diri mereka cukup berketerampilan bukan hanya dari segi ilmu kandungan, tetapi juga dari segi pedagogi sebelum mengajar perkara yang baharu kepada pelajar. Jika tidak, guru akan 'syok sendiri', manakala pelajar-pelajar akan 'terganga' (Utusan Malaysia, 2002). Hal yang sama pernah diutarakan oleh penyelidik sebelum ini. Misalnya Magdeline (2008) mengatakan gaya pengajaran yang dipilih oleh guru tidak semestinya disukai oleh pelajar. Menurut beliau lagi, jika hal sedemikian berlaku maka wujudlah situasi guru tersebut mengajar 'syok sendiri'. Dalam konteks mata pelajaran Bahasa Iban, pengajaran guru-guru bahasa Iban belum tentu dapat difahami dan diminati oleh pelajar-pelajarnya, tetapi guru pula menganggap pelajar-pelajarnya memahami dan meminati pengajarannya. Oleh yang demikian, guru tersebut yang mengajar 'syok sendiri', tetapi pelajar tidak mendapat manfaat daripada sesi pengajaran dan pembelajaran yang dihadiri kerana tidak dapat mengikuti serta memahami pengajaran guru.

Kajian tentang PPK dalam kalangan guru sekolah rendah dan menengah amat sedikit (Tengku Zawawi, 2005). Jika merujuk kepada mata pelajaran Bahasa Iban, setakat ini belum ada kajian tentang PPK dijalankan untuk sekolah rendah dan juga sekolah menengah. Kajian PPK terhadap mata pelajaran bahasa juga amat kurang di Malaysia. Setakat ini, kajian PPK di Malaysia hanya dilaksanakan oleh Nurul Hudaa et al. (2010) yang mengkaji PPK Bahasa Arab. Pengkaji yang lain lebih tertumpu kepada mata pelajaran Sains (misalnya Rosnidar, 2011; Mike 2010; Abdul Aziz, 2008; Lilia \& T. Subahan, 2002; Lilia, Abd. Razak, Abd. Rashid \& T. Subahan, 2001; Lilia 1997), mata pelajaran Matematik (misalnya Yusminah dan Effendi 2010; Norasliza dan Zaleha, 2008; Isamudin 2008; Tengku Zawawi 2005 \& Zaidah, 2005). Ada juga kajian PPK terhadap mata pelajaran lain seperti Kesusasteraan Melayu 
(Rozaiman, Zamri, Nor Izam \& A. Rahman, 2011), Pendidikan Moral (Abdul Shatar, 2007), Sejarah (Aini, 1996) dan Perdagangan (Nor Aishah \& Yap, 2002).

\section{OBJEKTIF KAJIAN}

Beberapa objektif untuk kajian ini telah dibina selari dengan tujuan kajian pengkaji. Objektif kajian ini adalah seperti yang berikut:

1. Menerangkan pengetahuan pedagogi kandungan (PPK) pengajaran bahasa Iban yang dimiliki oleh guru bahasa Iban yang berpengalaman dan guru bahasa Iban yang baharu.

2. Menjelaskan bagaimana pengetahuan isi kandungan subjek, pengetahuan pedagogi subjek dan pengetahuan terhadap ciri pelajar menghasilkan pengetahuan pedagogi kandungan (PPK) semasa pengajaran bahasa Iban.

\section{METODOLOGI}

\section{Reka Bentuk Kajian}

Reka bentuk kajian ini adalah kajian kualitatif jenis kajian kes. Reka bentuk kajian kualitatif difikirkan sesuai untuk menjalankan kajian ini memandangkan kajian ini bertujuan untuk mengumpulkan maklumat dan data untuk melihat gambaran pengetahuan pedagogi kandungan (PPK) pengajaran guru bahasa Iban sekolah menengah di Sarawak. Tiga orang guru bahasa Iban dari PPD Subis dan seorang dari PPD Miri telah menjadi peserta kajian kes, iaitu terlibat dalam temu bual dan pemerhatian.

\section{Peserta Kajian}

Sebanyak empat orang guru bahasa Iban dijadikan peserta kajian. Peserta kajian ini terdiri daripada dua orang guru bahasa Iban yang baharu dan dua orang guru bahasa Iban yang berpengalaman. Keempat-empat orang peserta kajian dikodkan sebagai Guru Bahasa Iban 1 (GBI1), GBI2, GBI3 dan GBI4. GBI1 dan GBI2 mewakili guru bahasa Iban yang baharu mengajar, manakala GBI3 dan GBI4 mewakilti guru bahasa Iban yang berpengalaman mengajar. 


\section{Instrumen}

Data diperoleh melalui temu bual, pemerhatian pengajaran guru, dan analisis dokumen. Oleh itu, pengkaji telah membina protokol temu bual, protokol pemerhatian dan borang pemerhatian Kesemua instrumen tersebut telah diubah suai dari pengkaji terdahulu seperti Tengku Zawawi (2005) dan Zaidah (2005). Kesahan dan kebolehpercayaan data kualitatif kajian ini boleh didapati serta dinilai melalui kajian rintis, triangulasi data, catatan nota lapangan, pengesahan peserta kajian dan pengesahan pakar.

\section{Kaedah Analisis Data}

Kajian ini mendapatkan data utama melalui temu bual serta disokong dengan data pemerhatian pengajaran dan juga analisis dokumen. Oleh itu, sebelum memulakan proses pemerolehan data, beberapa prosedur perlu dipatuhi oleh pengkaji untuk memastikan semua proses berjalan dengan lancar. Data kajian kualitatif ini dikaji secara teliti dengan bantuan QSR Nvivo9 untuk mengkategorikan tema atau pola yang timbul hasil dari kajian transkrip. Tema-tema tersebut kemudiannya dirujuk kepada pakar yang dilantik untuk mendapatkan pengesahan.

\section{DAPATAN KAJIAN DAN PERBINCANGAN}

\section{Perbezaan Pengetahuan Pedagogi Kandungan Guru Bahasa Iban Baharu dan Berpengalaman}

Pengetahuan Pedagogi Kandungan (PPK) guru bahasa Iban yang baharu dan berpengalaman dilihat dari segi pengetahuan mereka terhadap ciri pelajar, pengetahuan isi kandungan subjek dan pengetahuan pedagogi subjek. Dapatan kajian menunjukkan tidak ada perbezaan yang ketara di antara guru bahasa Iban yang baharu dan juga guru bahasa Iban yang berpengalaman. Perbezaan yang wujud hanya perbezaan yang kecil sahaja. Guru bahasa Iban baharu satu (GBI1) dan dua (GBI2) kurang memberi perhatian terhadap ciri pelajar jika dibandingkan dengan guru bahasa Iban berpengalaman tiga (GBI3) dan empat (GBI4). Walau bagaimanapun, ini bukan bererti GBI1 dan GBI2 tidak memberi perhatian langsung terhadap ciri pelajar mereka. 
"Ya, sangat penting. Seorang guru saya rasa dia perlu memahami pelajar dia dari segi....penerimaan pelajar itu, maksudnya kecekapan dia menerima, kebolehan dia menerima, setakat mana dia mampu...itu kita yang kena tahulah dari seseorang pelajar tu, supaya kita.. objektif kita untuk pelajar yang pandai, objektif dia lain, bukan lainlah mungkin kita banyakan sedikit selagi dia boleh terima kan. Kalau untuk pelajar yang kurang pandai, kelas yang hujung-hujung...terlebih dulu kita kena limitkan, kita kena tekankan satu objektif satu objektif.” GBII/TB/C/R1/2011

“Kita perlu faham tentang pelajar...supaya mudah untuk kita mengajar itu satu, latar belakang pelajar ini penting. Penting untuk kita memahami pelajar supaya nanti mudah untuk kita mengaplikasikan apa yang kita ajar dan mudah untuk pelajar faham sebab apa yang kita ajar tu adalah persamaan dengan apa yang mereka lalui dalam kehidupan seharian. Jadi menuntut ilmu tu mereka fahamlah." GBI2/TB/C/R2/2011

Dapatan temu bual tersebut menunjukkan bahawa guru-guru bahasa Iban yang baharu tahu mengenai kepentingan mengetahui ciri pelajar tetapi semasa pemerhatian oleh pengkaji didapati mereka tidak menunjukkan pengetahuan mereka terhadap ciri pelajar dalam setiap pemerhatian yang dijalankan oleh pengkaji. Perkara sebaliknya pula berlaku pada guru berpengalaman, guru berpengalaman menunjukkan mereka mengetahui tentang ciri pelajar dalam setiap pengajaran yang mereka laksanakan. Mereka menggunakan pengetahuan tersebut untuk merancang pengajaran yang berkesan. GBI3 mengatakan:

"Ya, bagi saya kita mesti faham dulu, maksudnya faham dulu kepandaian ataupun kecerdikan seseorang pelajar itu. Contohnya kalau kita mengajar di kelas yang pelajar yang lebih pandai terutamanya kelas di depan, cara kita mengajar itu ataupun mereka yang lebih banyak memberi idealah ataupun pendapat dalam bahasa ini. Tetapi apabila kita berada di kelas yang di hujung ataupun di kelas yang pelajar dia kurang cerdik, maka kita tidak boleh bagi dia perbincangan untuk 
mereka. Kita yang membimbing mereka, kita yang lebih banyak memberi idea untuk mereka, kemudian baharu mereka ikutlah." GBI3/TB/A/RI/2011

Tempoh mengajar mata pelajaran Bahasa Iban mempengaruhi penguasaan pengetahuan isi kandungan subjek. Guru yang lebih lama mengajar bahasa Iban walaupun pengalaman mengajar tidak lama, menunjukkan penguasaan isi kandungan yang lebih baik. Misalnya GBI3 hanya berpengalaman mengajar selama 13 tahun, tetapi telah mengajar bahasa Iban selama 13 tahun lebih menguasai pengetahuan isi kandungan bahasa Iban jika dibandingkan GBI4 yang telah mengajar selama 15 tahun dan berpengalaman mengajar bahasa Iban selama 13 tahun.

Pengetahuan pedagogi subjek guru bahasa Iban yang baharu masih lemah jika dibandingkan dengan guru bahasa Iban yang berpengalaman. Guru bahasa Iban yang berpengalaman (GBI3 dan GBI4) bersuara lantang dan sentiasa menyelitkan unsur-unsur kecindan dalam pengajaran dan pembelajaran mereka. Misalnya, setiap kali GBI3 mengedarkan edaran kepada pelajarnya, dia akan menyebut, "Nyadi nya diberi pengajar ngagai kita nadai bebayar. Bayar maya kita udah gawa ila" (Jadi ini cikgu beri secara percuma. Bayar bila kamu dah kerja nanti). Manakala GBI4 pula gemar menyebut, "Udah kitai belajar enda? Enti enda nemu chabut ku ngeli kita." (Kamu dah belajar kan? Kalau tak tahu saya cabut gigi kamu).

Melalui pemerhatian pengkaji, guru bahasa Iban yang baharu kurang mementingkan set induksi dan juga rumusan di akhir pengajaran. Manakala guru bahasa Iban yang berpengalaman sentiasa memulakan pengajaran dengan set induksi dan mengakhiri pengajaran dengan rumusan pengajaran. Guru bahasa Iban berpengalaman juga sentiasa memberi motivasi kepada pelajar-pelajarnya. GBI3 sentiasa menyebut "Tempap ke jari ngagai sida" (beri tepukan kepada mereka) setiap kali pelajarnya selesai melakukan tugasan yang diberi, sama ada membaca, menjawab soalan atau membentang hasil perbincangan. Beliau juga mengatakan, "Bacha baka ka dalam TV. Bacha amat-amat ka. Ni nemu ila macha berita ba TV1 kini..TV3 kini.." (Baca seperti dalam TV. Baca dengan betul. Mana tahu suatu hari nanti membaca berita untuk TV1 ke...TV3 ke....). 
Guru bahasa Iban yang baharu dan juga berpengalaman sama-sama menggunakan pelbagai kaedah dalam pengajaran dan pembelajaran mereka. Namun yang berbeza ialah guru bahasa Iban baharu lebih menggunakan teknologi maklumat, tetapi perkara yang berbeza pula berlaku dalam pengajaran dan pembelajaran guru bahasa Iban yang berpengalaman. Dari segi pengurusan bilik darjah pula, guru baharu kurang menekankan pengurusan bilik darjah. GBI1 dan GBI2 lebih fokus kepada menyampaikan isi pelajaran setiap kali memasuki bilik darjah. Berbeza pula dengan GBI3 dan GBI4 yang tidak akan memulakan pengajaran selagi tidak berpuas hati dengan kebersihan bilik darjah. Guru berpengalaman juga akan mengesan kehadiran pelajarnya terlebih dahulu sebelum memulakan sesi pengajaran. GBI3 memang menegaskan sebab beliau mementingkan pengurusan bilik darjah. Menurut beliau, "Kadangkala mereka main cucuk sana cucuk sini. Itulah maksudnya kita perlu kawalkan kelas dululah."

Dapatan pemerhatian menunjukkan guru berpengalaman mengamalkan kerja secara berkumpulan, tetapi guru baharu lebih kepada kerja secara individu. Guru berpengalaman juga akan menunjuk cara bagaimana untuk membaca dengan betul atau menjawab soalan dengan betul. Sebaliknya, guru baharu jarang membimbing pelajar dengan menunjuk cara. Jika kajian lampau seperti Feiman-Nemser dan Parker (1990) mendapati guru baharu mempunyai PPK yang kurang lengkap dan cetek, serta guru dikatakan mengajar tanpa mengubah suai, keadaan amat berbeza dengan dapatan kajian ini. Tidak jauh beza tahap PPK guru baharu dan guru berpengalaman. Kajian ini mendapati bahawa faktor keperibadian guru yang membezakan penguasaan PPK guru, sama ada guru tersebut baharu atau berpengalaman hanya menjadi faktor sampingan sahaja. Guru baharu yang menjadi peserta kajian ini menunjukkan inisiatif dan daya usaha yang tinggi untuk mendalami mata pelajaran Bahasa Iban serta berusaha mencipta dan juga menyedia bahan bantu mengajar didapati mempunyai PPK yang lebih baik daripada guru berpengalaman yang bersikap sebaliknya. Malah, guru-guru baharu lebih menguasai teknologi yang membolehkan mereka mengubah suai pengajaran selaras dengan kepesatan teknologi. Dapatan ini selari dengan kajian Chen Yuen Fook, Gurnam Kaur, Fatin Alianam, Parmjit \& Md. Rizal, (2012) di mana didapati guru terlatih (berpengalaman) lebih banyak menerapkan aspek kemahiran berbanding guru tidak terlatih (baharu). 
Secara keseluruhan, boleh disimpulkan tidak ada perbezaan yang ketara antara guru yang berpengalaman dan guru yang baharu. Keadaan ini selari dengan dapatan Tengku Zawawi (2005) dalam kajiannya terhadap guru Matematik. Guru baharu menguasai PPK melalui teknologi terkini seperti kemahiran ICT. Pembacaan dan pencarian bahan melalui Internet banyak membantu guru-guru baharu. Guru-guru lama pula banyak bergantung kepada pengalaman dan pengumpulan ilmu serta bahan selama bertahun-tahun telah mengajar.

\section{Penghasilan Pengetahuan Pedagogi Kandungan Guru Bahasa Iban}

Penguasaan tiga komponen, iaitu pengetahuan isi kandungan, pengetahuan pedagogi subjek dan pengetahuan terhadap ciri pelajar akan menghasilkan pengetahuan pedagogi kandungan guru bahasa Iban. Pengetahuan isi kandungan dipengaruhi oleh kesedian guru, pandangan guru terhadap kurikulum bahasa Iban, pengetahuan isi kandungan guru dan pandangan guru terhadap kepentingan pengetahuan isi kandungan. Manakala pengetahuan pedagogi subjek pula akan mempengaruhi pendekatan yang diamalkan guru dan penyampaian guru.

Kesediaan guru merujuk kepada kerelaan guru untuk mengajar bahasa Iban memandangkan semasa kajian ini dijalankan semua guru bahasa Iban bukan pengkhususan bahasa Iban. Kesediaan guru juga merangkumi kerelaan guru untuk menimba sendiri ilmu bahasa Iban dengan cara masing-masing. Misalnya GBI3 mengatakan, "Macam saya terpaksa bertanya dengan kawan-kawan sekolah yang berdekatan ataupun yang mengajar Bahasa Iban di sekolah yang sama." (GBI3/TB/A1/R1/2011). GBI3 pula berpendapat, "At least cikgu tu dia perlu ada latar belakang yang jelaslah tentang benda-benda ni sebelum kita mengajar." (GBI2/TB/A1/R1/2011).

Pandangan guru bahasa Iban terhadap kurikulum bahasa Iban akan mempengaruhi pengetahuan isi kandungan mereka. Guru yang bersikap negatif terhadap kurikulum bahasa Iban akan menyebabkan pengetahuan isi kandungan mereka kurang kerana sentiasa mencari pelbagai alasan dalam melaksanakan kurikulum bahasa Iban. GBI1 memberi komen berikut: 
"Oleh sebab saya baharu sahaja mengajar sembilan bulan jadi terus terang saya katakan, saya tidak begitu tahulah, tidak begitu mengetahui, bukan tidak mengetahui langsung tetapi tidak begitu mengetahuilah kurikulum." (GBI1/TB/A3/R1/2011)

"Pada pandangan saya mengenai kurikulum yang dibina ataupun untuk panduan kita mengajar bahasa Iban ni. Kadang-kala rasanya bagi kitalah sukar. Kadang-kala sukar untuk kita mengikut betul-betul yang spesifik dalam kurikulum tu sebab dia bergantung kepada apa yang sebenarnya... dia bergantung kepada keadaan ataupun faktor pelajar di sekolah itu. Lagipun dari segi bahasa kadang-kala pelajar ini, di kawasan ini cara bahasa dia lain. Apabila di sekolah yang lain, di tempat yang lain dia tidak sama. Jadi kalau boleh, kita permudahkan lagi kurikulum yang sedia ada tu. Kalau boleh kita ikutlah, terima balik pandangan macam di ulu...di kawasan ulu. Macam di bandar dia sudah bercampur dengan...bahasa Iban ni sudah bercampur dengan bahasa yang lain. Jadi kalau boleh itu, diterimalah masuk dalam kurikulum yang akan kita binalah....pendapat saya." (GBI3/TB/A3/R1/2011)

Pengetahuan isi kandungan bahasa Iban juga terhasil daripada pengetahuan isi kandungan guru bahasa Iban itu sendiri yang terbentuk dari pengalaman hidup dan masyarakat setempat. Misalnya, pengetahuan isi kandungan leka main (puisi Iban) yang digunakan oleh guru bahasa Iban untuk mengajar bahagian puisi adalah berdasarkan pengetahuan sedia ada guru-guru bahasa Iban itu sendiri. Oleh itu, pengkaji dapati pengertian dan pengajaran puisi Iban ini juga dipengaruhi oleh kepercayaan masyarakat setempat guru bahasa Iban tersebut.

"Pendapat saya leka main ini adalah salah satu bahasa seperti bahasa... contohlah adalah satu adat ataupun, bukan adatlah lebih kepada hiburan. Kadangkala apabila... kalau dia Ganu ataupun Pantun, dia lebih kepada puisilah... puisi zaman dahulu. Kalau dalam bahasa Melayulah puisi, syair contohnya yang leka main ini. Kalau dia ada dua, kadangkala kalau kita 
kata Sampi dan Biau, itu dia lebih..leka main dia lebih kepada cara kita dulu. Cara perubatan kalau dalam Manang ataupun Timang, lebih kepada untuk menyembuhkan orang sakit dan sebagainyalah. Pendapat saya.. kalau untuk leka main inilah. Tetapi apabila diajar di sekolah, benda ini hanya umum sajalah yang diajar di sekolah itu... yang macam rasanya yang senang-senang sahaja. Kalau yang rasanya yang betul-betul tu kadangkala kalau kita membuat Sampi dan Biau, kita buat sebutan dia itu. Kita tidak boleh ambil sebutan yang betul-betul macam kita nak errr.. apa nama tu yang lama-lama kadangkala kalau kita nak buat Sampi dan Biau ni mesti dia menggunakan Piring dan sebagainya. Nanti sebab kita ni masih... kadang-kala orang tua kata "eh jangan buat macam tu. Itu tidak boleh kamu sebut nanti sakit kita." Haa... itu kengkangan untuk leka main inilah pada pendapat saya." (GBI3/TB/A4/R1/2011)

"Yang secara peribadi, leka main yang saya tahu dia adalah permainan. Bukan permainan, adalah puisi. Puisi-puisi lama. Puisi klasik yang selalu digunakan dalam masyarakat dalam pelbagai aktivitilah. Contohnya acara adat, acara kematian, waktu orang berubat dan juga tidak ketinggalan jugalah waktu pesta macam gawai, leka main ini adalah...memang dalam majlis-majlis seperti ni." (GBI2/TB/A4/R1/2011)

Pandangan guru terhadap kepentingan pengetahuan isi kandungan juga akan menyumbang kepada penghasilan pengetahuan pedagogi kandungan guru bahasa Iban. Hal ini kerana guru yang merasakan betapa penting penguasaan pengetahuan isi kandungan akan mencari lebih maklumat tentang pengajarannya untuk menghadapi sebarang persoalan yang akan dikemukakan oleh pelajar mereka.

"Ok. Dia lebih kepada kita tahu contentlah. Seorang guru sebelum dia masuk ke dalam kelas, sebelum menyampaikan sesuatu itu sudah semestinya dan sepatutnyalah seorang cikgu itu dari segi isi kandungan itu dia kena tahu secara mendalam atau 
dengan lebih dalamlah isi kandungan itu sebelum dia sampaikan kepada pelajar. Sebab kita takut nanti bila pelajar kan dia rasa ingin tahu.... bila dia bertanya lebih daripada content...kadang-kadang pelajar ni ada pelajar yang baik, yang akan bertanya lebih daripada silibus itu, lebih daripada apa yang kita nak ajar. Jadi kita.. kalau sekiranya seorang guru itu dia tidak bersedia, maklumat yang nak disampaikan itu tidak kesampaianlah. Pelajar itu tidak dapat apa yang dia nak." (GBI1/TB/A2/R1/2011)

\begin{abstract}
"Seseorang guru itu perlulah mempunyai pengetahuan tentang isi kandungan dalam mata pelajaran yang dia ajar. Contohnya dalam pengajaran bahasa Iban ini. Guru itu perlulah dapat menguasai contohnya, kosa kata di dalam pelajaran itu untuk memudahkan guru itu menyampaikan pengajaran dengan lebih berkesan untuk murid-murid mereka. Murid-murid dialah." (GBI4/TB/A1/R2/2011)
\end{abstract}

Pengetahuan pedagogi kandungan guru terhasil apabila guru menguasai pedagogi subjek yang akan diajar. Hal ini kerana guru yang menguasai pedagogi subjek akan menggunakan pelbagai pendekatan dalam proses pengajaran dan pembelajaran mereka. Dapatan kajian ini mendapati kesemua peserta kajian telah melibatkan pelajar masing-masing secara aktif semasa proses pengajaran dan pembelajaran berlangsung. Kesemua peserta kajian menggunakan teknik penyoalan untuk melibatkan pelajar secara aktif. Selain itu, ada juga peserta kajian, iaitu GBI3 mencabar pelajarnya supaya terlibat secara aktif.

"Sapa ke berani, mansang kitu macha pantun tu." (siapa yang berani, maju ke depan membaca pantun ini) $(G B I 3 / P 4 / B 3 / R 1 / 2011)$

Peserta kajian juga menunjuk cara sebelum mengarahkan pelajar membaca atau melaksanakan tugasan yang diberikan. Tunjuk cara amat penting dalam pembelajaran bahasa Iban khususnya semasa sesi pembelajaran bahagian puisi Iban. GBI3 sentiasa tunjuk cara terlebih dahulu sebelum mengarahkan pelajar-pelajarnya: 
"Nyadi diatu kita ninga dulu, udah nya aku ngagau ke sapa bala kita ti berani macha ai ansah tu ba mиa ditu." ( Sekarang ini kamu dengar dulu, selepas ini saya akan panggil sesiapa yang berani untuk membaca ai ansah di hadapan kelas) (GBI3/P2/B7/R1/2011)

Kesemua peserta kajian juga sentiasa memberi latih tubi untuk mengukuhkan kefahaman pelajar terhadap topik yang mereka ajar. GBI3 dan GBI4 akan menerangkan erti perkataan yang susah terlebih dahulu untuk membantu kefahaman pelajar terhadap teks yang mereka baca.
"Nyadi kitai meda senteli ngagai siti senteli. Ok..ari rangkap ke rangkap..ari sebaris ayat ngagai sebaris ayat." (Kita akan lihat perengan demi perengan. Ok... dari rangkap ke rangkap... dari setiap baris ayat) (GBI4/P1/B5/R1/2011)

Selain itu, guru juga bercerita untuk membantu kefahaman pelajar. Teknik bercerita bukan hanya boleh membantu kefahaman pelajar, tetapi juga boleh menarik perhatian pelajar terhadap isi yang ingin disampaikan oleh guru. Berikut adalah contoh cerita GBI3 semasa sesi pengajarannya.

"Sebedau kitai ka ngaga latih tu, aku ka madah ka bala kita keni ka macha ai ansah tu. Nyadi ai ansah tu kena aki ini kitai kelia. Diatu jarang pengajar meda tauka ninga ai ansah. Menya kena orang maya pengerami... maya melah pinang. Chunto iya, aku tu enggau Roger kangambi indu, aku asuh orang bejaku...nyadi aku deka diansah ambi aku nemu bejaku. Ai ansah tu tadi reti iya ai tuak beri orang ngambi pandai bejaku. Udah iya ngirup nya tadi lalu pandai iya bejaku” (Sebelum kita membuat latihan ini, saya akan terangkan bagaimana membaca ai ansah ini. Ai ansah (sejenis puisi Iban) digunakan oleh nenek moyang kita dahulu. Sekarang ini jarang cikgu melihat atau mendengar ai ansah. Dahulu digunakan semasa majlis keraian....masa perkahwinan. Contohnya, saya dan Roger menghadiri majlis perkahwinan, saya diwakilkan berucap...jadi saya akan diansah supaya pandai berucap. Ai ansah 
ini sebenarnya ai tuak yang diberi supaya pandai berucap. Selepas minum air tu tadi terus pandai berucap. (GBI3/P2/B7/R1/2011)

Satu lagi pendekatan yang diamalkan oleh peserta kajian adalah memberi motivasi kepada pelajarnya. Guru-guru menyelitkan unsur motivasi ini dalam sesi pengajaran mereka. Misalnya, GBI3 memotivasi pelajarnya untuk membaca dengan ayat-ayat seperti berikut, "Sapa ka? Siku da lelaki, bujang berani.” (Siapa mahu? Seorang lagi lelaki, jejaka berani) dan "Diatu kitai minta lelaki agi bepantun. Enda patut lelaki alah laban orang indu" (Sekarang kita minta lelaki pula berpantun. Tidak patut lelaki kalah dengan perempuan).

Penyampaian guru memainkan peranan penting dalam proses pengajaran dan pembelajaran. Pilihan pendekatan yang sesuai tidak memandai untuk menyampaikan ilmu kepada pelajar jika penyampaian guru kurang jelas. Dapatan pemerhatian pengkaji mendapati kesemua guru bahasa Iban yang menjadi peserta kajian mempunyai suara yang lantang dan jelas. Suara yang lantang amat penting dalam pengajaran mata pelajaran Bahasa Iban kerana saiz kelas yang besar. Kelas bahasa Iban GBI1 misalnya terdiri daripada 45-50 orang pelajar kerana gabungan dua hingga tiga kelas.

Pengetahuan pedagogi kandungan guru amat berkait rapat dengan pengetahuan guru tersebut terhadap ciri-ciri pelajarnya. Tanpa pengetahuan tentang ciri-ciri pelajar, pengajaran seseorang guru sudah pasti kurang berkesan kerana pendekatan yang dipilih mungkin kurang sesuai dengan kebolehan serta keperluan pelajar yang akan diajarnya. Dapatan kajian ini mendapati, pengetahuan pedagogi kandungan guru bahasa Iban terhasil kerana kesemua peserta kajian mengambil berat tentang ciri-ciri pelajar mereka semasa membuat persiapan mengajar.

“Ok... yang pertama yang saya lihatlah, kita perlu faham latar belakang pelajar sejauh mana mereka faham apa yang kita ajar. Contohnya kalau kita ambil perbandingan Bahasa Iban tadi kita kena tahu...sebab Bahasa Iban ni dialek dia mungkin berbeza daripada bahagian-bahagian lain." (GBI2/TB/C/R1/2011) 
"Ok... di samping itu, guru juga kena mengetahui tentang pelajar dia. Contohnya, tahap kebolehan pelajar itu, dari segi cara pelajar itu menulis, cara pelajar itu bercakap, kosa kata mereka” (GBI4/TB/C/ R1/2011)

Semasa kajian ini dijalankan, semua guru bahasa Iban adalah dari pelbagai pengkhususan. Namun demikian, guru-guru bahasa Iban tersebut telah mula menguasai pengetahuan pedagogi kandungan mata pelajaran yang bukan pengkhususan mereka. Kajian lampau telah membuktikan bahawa guru pengkhususan tidak semestinya mempunyai kefahaman yang mendalam dan dapat mengaitkan tajuk yang diajar dengan baik (Abdul Shatar 2007). Dapatan kajian ini menyokong dapatan Abdul Shatar (2007) kerana walaupun semua guru-guru bahasa Iban bukan pengkhususan bahasa Iban, malah ada antaranya tidak memiliki latar belakang pengkhususan Bahasa Melayu atau Kesusasteraan Melayu, tetapi mereka tetap memiliki kefahaman yang baik terhadap tajuk yang diajar. Hal ini bermakna, dapatan ini juga berbeza dengan dapatan Hashweh (1987) yang mengatakan guru pengkhususan mempunyai kefahaman yang mendalam dan dapat mengaitkan tajuk yang diajar dengan baik.

\section{KESIMPULAN}

Pengetahuan Pedagogi Kandungan (PPK) secara ringkasnya boleh ditafsirkan sebagai pengetahuan berhubung dengan isi kandungan dan cara penyampaian isi kandungan tersebut dengan berkesan. PPK guru bahasa Iban yang baharu dan berpengalaman tidak mempunyai perbezaan yang ketara. Walau bagaimanapun, masih tetap wujud sedikit perbezaan antara guru bahasa Iban yang baharu dan juga berpengalaman yang dipengaruhi oleh faktor sikap guru berkenaan. Dapatan kajian mendapati bahawa guru bahasa Iban akan menguasai PPK dengan baik jika mereka dapat menguasai pengetahuan isi kandungan, pengetahuan pedagogi subjek dan juga pengetahuan terhadap ciri pelajar mereka.

Penguasaan PPK guru akan menentukan mutu pengajarannya yang secara langsung akan mempengaruhi hasil pengajaran seseorang guru. Dalam lain perkataan, guru yang menguasai PPK akan dapat mengajar bahasa Iban dengan lebih berkesan jika dibandingkan 
dengan guru yang kurang menguasai PPK. Oleh itu, PPK seharusnya diterapkan bermula dari peringkat akar umbi sistem pendidikan guru iaitu sejak latihan perguruan. Amat membantu juga jika guru-guru bahasa Iban yang sedia ada diberi khusus jangka pendek untuk memberi pendedahan tentang PPK bahasa Iban.

\section{RUJUKAN}

Abdul Aziz Abd Kadir. (2008). Menentukan komponen-komponen pengetahuan pedagogikal kandungan (PPK) guru Biologi Matrikulasi. Tesis Sarjana Pendidikan. Bangi: Universiti Kebangsaan Malaysia.

Abdul Shatar Che Abd Rahman. (2007). Pengetahuan kandungan dan pedagogi guru Pendidikan Moral tingkatan 4 di sebuah sekolah. Tesis Doktor Falsafah. Kuala Lumpur: Universiti Malaya.

Aini Hassan. (1996). A study of Malaysian History teachers' subject matter and pedagogical content knowledge. Tesis Ed.D. Monash University. Australia.

Asmah Haji Omar \& Rohani Mohd Yusof. (1988). Bahasa Iban dan pengajarannya di peringkat pengajian tinggi. Dewan Bahasa. Ogos: 548-561.

Asmah Hj Omar. (1981). The Iban language of Sarawak: A grammatical description. Kuala Lumpur: Dewan Bahasa \& Pustaka.

Asmah Hj Omar. (1985). Susur galur bahasa Melayu. Kuala Lumpur: Dewan Bahasa \& Pustaka. Asmah Hj Omar. (1993). Perkaitan Bahasa Melayu dengan Bahasa Iban dari segi sejarah. Dlm. Nik Safiah Karim (pnyt). Tinta sejarah, 39-55. Kuala Lumpur: Jabatan Pengajian Melayu Universiti Malaya. Ball, D. L, Thames M. H., \& Phelps, G. (2008). Content knowledge for teaching: what makes it special? Journal of Teacher Education, 59(5), 389-407.

Bernama. (2006). Bahasa Iban jadi subjek SPM pada 2008. Bernama. com. http://www.bernama.com.my. [26 Ogos 2010].

Borko, H. \& Putnam, R.T. (1996). Learning to teach. Dlm. D.C Berliner \& R.C. Calfee (Eds.), Handbook of educational psychology. Boston: Macmillan.

Burns \& Lash. (1988). Nine seventh-grade teachers' knowledge and planning of problem-solving instruction. The Elementary School Journal, 88 (4), 369-386. 
Carter, K. (1990). Teachers' knowledge and learning to teach. Dlm. W. R Houston, M., Haberman \& J. Sikula (Eds.). Handbook of research on teacher education, 42-56. New York: Macmillan.

Chen Yuen Fook, Gurnam Kaur Sidhu, Fatin Aliana Mohd Radzi, Parmjit Singh \& Md. Rizal Md. Yunus. (2012). Penilaian kemahiran guru Sejarah dan Geografi dalam pelaksanaan kerja kursus di peringkat sekolah menengah rendah. Malaysian Journal of Learning Instruction, 9 (2012), 47-80.

Chemaline anak Osup. (2006). Leka main Puisi rakyat Iban: Satu analisis bentuk dan fungsi. Tesis Doktor Falsafah. Universiti Sains Malaysia, Pulau Pinang.

Chong Shin. (2006). Bahasa Iban dan dialek Melayu di Saribas, Sarawak. The Sarawak Museum Journal, LXII (83), 85-106.

Chong Yee Pei (2000). Tugas guru dan suasana pengajaran pendidikan moral di sekolah. Dlm. Abdul Shatar Che Abd Rahman. Pengetahuan Kandungan dan pedagogi guru Pendidikan Moral tingkatan 4 di sebuah sekolah. Tesis Doktor Falsafah. Universiti Malaya, Kuala Lumpur. http:// dspace.fsktm.um.edu.my [10 Julai 2010]

Collins, J.T. (2004). Ibanic languages in Kalimantan Barat, Indonesia: Exploring nomenclature, distribution and characteristics. Borneo Research Bulletin, 35, 17-47.

Feiman-Nemser, S. \& Parker, M. B. (1990). Making subject-matter part of the conversation in learning to teach. Journal of Teacher Education, 41 (3), 32-43.

Gess-Newsome, J. (1999). Pedagogical Content knowledge: An introduction and orientation. Dlm. J. Gess-Newsome, \& N.G. Lederman, (Eds.). Examining pedagogical content knowledge. Boston: Kluwer Academic Publishers.

Grasha, A. F. (1996). Teaching with style. El Paso. University of Texas. (atas talian) http://www.lib.utexas.edu (29 Julai 2010) Gudmundsdottir, S. (1991). Pedagogical model of subjeck matter. Dlm. J. Brophy, (Eds.). Advanced in research on teaching, 2: 265-304. New York: Pergamon.

Hashweh, M. Z. (1985). An exploratory study of teacher knowledge and teaching: The effects of science teachers' knowledge of subject matter and their conceptions of learning on their teaching. Dlm. Abdul Shatar Che Abd Rahman, Pengetahuan kandungan dan pedagogi guru Pendidikan Moral tingkatan 4 di sebuah sekolah. Tesis Doktor Falsafah. Universiti Malaya. http://dspace.fsktm.um.edu.my [10 Julai 2010] 
Ingber, J. D. (2009). A comparison of teachers' pedagogical content knowledge while planning in and out of their Science expertise. Columbia: Columbia University Press.

Isamudin Rasip. (2008). Pengetahuan pedagogikal kandungan (PPK) guru Matematik Tambahan sekolah menengah: Satu kajian kes. Kertas Projek Sarjana Pendidikan. Bangi: Universiti Kebangsaan Malaysia.

Ismail Jusoh. (1991). Kajian bandingan fonologi Bahasa Melayu dan Bahasa Iban. Jurnal Dewan Bahasa, 35 (2), 146-172.

Kauchak, D.P. \& Eggen, P.D. (2007). Learning and teaching: Research-based method. New York: Pearson Education.

Lambat anak Lindong. (2007). Sejarah bahasa Iban di sekolah di Sarawak. Unit Bahasa Etnik, Pusat Perkembangan Kurikulum, KPM.

Lilia Halim \& Norlena Salamuddin. (2000). Orientasi akademik: Pendekatan alternatif dalam program pendidikan guru siswazah di Malaysia. Akademika, 56, 47-64.

Lilia Halim \& T.Subahan Mohd Meerah. (2002). Science trainee teachers' pedagogical content knowledge and its influence on physic teaching. Research in Science \& Technological Education, 20(2), 215-260.

Lilia Halim, Abd Razak Habib, Abd Rashid Johar \& T. Subahan Meerah. (2001). Tahap pengetahuan pedagogi kandungan guru pelatih Fizik dan bukan Fizik melalui pengajaran eksplisit dan implisit. Jurnal Pendidikan, 26, 65-80.

Magdeline anak Nor. (2008). Sikap pelajar terhadap mata pelajaran Bahasa Iban dan pertaliannya dengan gaya pengajaran guru. Kertas Projek Sarjana Pendidikan. Bangi: Universiti Kebangsaan Malaysia.

Magnusson, S., Borko, H. \& Krajcik, J. (1998). Nature, source, and development of pedagogical content knowledge for Science teaching. Dlm J. Gess-Newsome, \& N. Lederman, (Eds.). Knowledge for science teaching. Boston: Kluwer Academic Publishers.

May, M. H. C, Annie, Y. N. C \& Sylvia, Y. H. T. (2010). Closing the gap between the theory and practice of teaching: Implications for teacher education programmes in Hong Kong. Journal of Education for Teaching, 36 (1), 91-104.

Mazlini Adnan, Effandi Zakaria \& Khalid Abdullah. (2010). Kepercayaan Matematik dan hubungannya dengan pengetahuan konseptual dan pengalaman Matematik dalam kalangan guru 
praperkhidmatan. Prosiding Seminar Penyelidikan Siswazah, 201 (206) http://pkukmweb.ukm.my [10 Julai 2010]

Muhamet Usak. (2009). Preservice Science and technology teachers' pedagogical content knowledge on cell topics. Educational Sciences: Theory and Practice, 9 (4), 2033-2046.

Norasliza Hassan \& Zaleha Ismail. (2008). Kertas kerja Seminar Kebangsaan Pendidikan Sains dan Matematik: Pengetahuan pedagogi kandungan guru pelatih Matematik sekolah menengah. Universiti Teknologi Malaysia. 11-12 Oktober. http://eprints.utm.my [31 Ogos 2010]

Noriah Mohamed. (1994). Waktu pisah dan tingkat kekerabatan Bahasa Melayu dengan Bahasa Iban. Jurnal Dewan Bahasa, 38 (2), 129-142.

Nurul Hudaa Hassan, Nik Mohd Rahimi Nik Yusof \& Kamarul Zaman Abdul Ghani. (2010). Pengetahuan pedagogi isi kandungan bagi tajuk Isim Ai-Adad Wa Al-Ma'dud dalam kalangan guru Bahasa Arab sekolah menengah. Prosiding seminar penyelidikan siswazah. Jilid 202 /202010/bil 204. http://pkukmweb.ukm.my [10 Julai 2010].

Rahim Aman. (1997). Kebersamaan morfologi kelompok Ibanik dan Inovasi $\{\mathrm{Di}\}$ Ibanik + Bahasa Melayu. Jurnal Dewan Bahasa, 41(9), 842-846.

Rahim Aman. (2006). Perbandingan fonologi dan morfologi bahasa Iban, Kantuk dan Mualang. Kuala Lumpur: Dewan Bahasa \& Pustaka.

Rosnidar Mansor, Lilia Halim \& Kamisah Osman. (2010). Pengetahuan pedagogi isi kandungan guru (PPIK) dan kefahaman konseptual pelajar dalam topik Respirasi. Prosiding Seminar Penyelidikan Siswazah UKM, 1 (4), 251260. Bangi: Fakulti Pendidikan UKM.

Rosnidar Mansor. (2011). Pengetahuan pedagogikal isi kandungan (PPIK) guru dan kefahaman konseptual pelajar dalam topik Respirasi (Tesis PhD yang tidak diterbitkan). Bangi: Fakulti Pendidikan, Universiti Kebangsaan Malaysia.

Rozaiman Makmun, Zamri Mahamod, Noor Izam Mohd Taib \& A. Rahman Haron. (2011). Pengetahuan teknologi pedagogi kandungan kesusasteraan Melayu: Peranan guru sastera dalam SPN 21. Jurnal Pendidikan Bahasa Melayu, 1(2), 85-98.

Sarawak Government Official Portal. (2010). Sarawak. Dicapai daripada http://www.sarawak.gov.my 
Shahidi Abd Hamid. (2000). Analisis fonologi bahasa Iban. Jurnal Dewan Bahasa, 44(4), 434-444.

Shulman, L. S. (1986). Those who understand: Knowledge growth in teaching. Educational Researcher, 15(2), 4-14.

Shulman, L. (1987). Knowledge and teaching: Foundation of new reform. Havard Educational Review, 57(1), 1-22.

Siti Mistima Maat. (2011). Hubungan antara kepercayaan Matematik, amalan pengajaran dan pengetahuan pedagogi kandungan guru Matematik sekolah menengah (Tesis $\mathrm{PhD}$ yang tidak diterbitkan). Bangi: Fakulti Pendidikan, Universiti Kebangsaan Malaysia.

Solis, A. (2009). Pedagogical content knowledge: What matters most in the professional learning of content teachers in classrooms with diverse student populations. Intercultural Development Research Association (IDRA) newsletter. http://www.idra. org [10 Julai 2010]

Tengku Zawawi Tengku Zainal. (2005). Pengetahuan pedagogi isi kandungan bagi tajuk pecahan dalam kalangan guru Matematik sekolah rendah (Tesis PhD yang tidak diterbitkan). Bangi: Fakulti Pendidikan, Universiti Kebangsaan Malaysia.

Turnuklu, E. B., \& Yesildere, S. (2004). The pedagogical content knowledge in mathematics: pre-service primary mathematics teachers' perspectives in Turkey. IUMPST: The Journal. (2007 October 1: 1-13)

Unit Bahasa Etnik. (2007c). Laporan mesyuarat pegawai bahasa pejabat pelajaran daerah/gabungan/daerah kecil: Status pelaksanaan mata pelajaran Bahasa Etnik di sekolah (Iban, Kadazandusun dan Semai). Holiday Inn Kuching, 6-9 Mei 2007. Pusat Perkembangan Kurikulum.

Unit Bahasa Etnik. (2010a). Rumusan data perlaksanaan kurikulum bahasa Iban sekolah menengah. Putrajaya: Pusat Perkembangan Kurikulum, KPM.

Unit Bahasa Etnik. (2010b). Data bahasa Iban sekolah rendah dan sekolah menengah mengikut daerah di Saawak. Putrajaya: Bahagian Pembangunan Kurikulum, KPM.

Utusan Malaysia. (2002). Pisahkan isu penguasaan bahasa Inggeris. Dicapai daripada http://utusan.com.my

Veal, W. R. (1999). The TTF model to explain pedagogical content knowledge in teacher development. Paper presented at the Annual Meeting of The National Association For Research. http://www.eric.ed.gov. [26 Ogos 2010] 
Veal, W. R \& Makinster, J.G. (1999). Pedagogical content knowledge taxanomies. Electronic Journal of Science Education. Retrieved from http://wolfweb.unr.edu

Wiseman, D. L., Cooner, D.D. \& Knight, S.L. (1999). Becoming a teacher in a field-based setting: An introduction to education and classrooms. Boston: Wadsworth.

Yusminah Mohd Yusof \& Effendi Zakaria. (2010). Investigating secondary mathematics teachers' pedagogical content knowledge: A case study. Journal of Education and Sociology. Zaidah Yazid. (2005). Pengetahuan pedagogikal kandungan (PPK) guru Matematik Tambahan berpengalaman: Satu kajian kes (Tesis $\mathrm{PhD}$ yang tidak diterbitkan). Bangi:Universiti Kebangsaan Malaysia. 